\title{
Effective functioning of enterprises with regard to environmental risks
}

\author{
Victor Vasilenok ${ }^{1}$, Eduard Korovin ${ }^{2}$, Evgenia Aleksashkina ${ }^{3 *}$, Tatyana Kochegarova ${ }^{4}$ \\ ${ }^{1}$ D.Sc. Economics, Professor, Faculty of Technology Management and Innovation, ITMO University, \\ 191187, ul. Tchaikovsky 11/2, St. Petersburg, Russia \\ ${ }^{2}$ D.Sc. Economics, Associate Professor, Head of the Department of Economics and Law, Staint- \\ Petersburg University of State Fire Service EMERCOM of Russia, St. Petersburg, Russia \\ ${ }^{3}$ Senior Lecturer at the Faculty of Technology Management and Innovation, ITMO University, \\ 191187, ul. Tchaikovsky 11/2, St. Petersburg, Russia \\ ${ }^{4}$ Environmental Protection Engineer (ecologist), CJSC "PA “Trek”, 456306, ul. Gottwald 31, Miass, \\ Chelyabinsk Region, Russia
}

\begin{abstract}
The relevance of the chosen topic of the paper is caused by the need to analyze environmental risks arising during the operation of industrial, treatment and processing enterprises. The external and internal factors affecting the development and life cycle of an enterprise are presented. In order to understand how to solve problems associated with environmental risk, it is necessary to study the interaction of an enterprise with the environment in such areas as resource provision, production and sales of products. The system of effective functioning of an industrial enterprise is presented schematically. As a conclusion, it should be noted that the enterprise's management team should pay increased attention to external and internal factors that may cause environmental risks.
\end{abstract}

\section{Introduction}

The problem of environmental risks always remains relevant and in demand. The economic activity of industry dictates the constant monitoring and regulation of emissions to the environment by commercial and non-profit organizations involved in quality management and quality system audit. Industrial enterprise is considered as an element of the socio-economic system, i.e. the organizational and production system. An enterprise, like any living organism, is able to integrate all types of resources in its structure: material, financial, human, informational and others. Capacity building and its utilization contribute to making management decisions in the allocation of resources.

\section{Main part}

The strategic plan for the development of an enterprise should be oriented towards the trends of the society, which form the concept of an effective functional that takes into

\footnotetext{
* ealexashkina@mail.ru
} 
account the direction of actions, increase in efficiency and, consequently, increase in the economic effect. [1] It should not be forgotten that enterprises are a large-scale structural element of the external environment, and the preservation of the ecological situation largely depends on the conscientious attitude of managers and owners of industrial production (Figure 1).

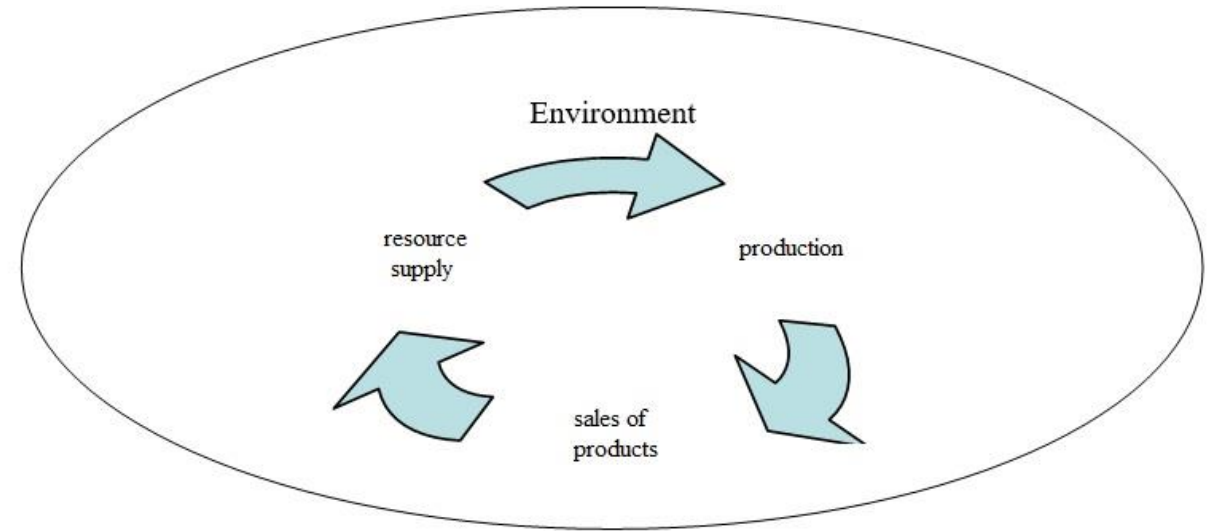

Fig. 1. Cyclical process of implementing the main tasks of an industrial enterprise in the environment

The implementation of the three-stage production cycle allows the enterprise to function effectively [2]. Thus, the harmonious interaction of all elements of the system is determined by the need to implement resource supply, efficient production, efficient distribution, and efficient management, which are presented in Figure 2.

An enterprise that effectively interacts with the environment can predict the possibility of environmental risks, and as a result, plan a quality management system in the organization. The issue of greening is relevant in modern conditions, since statistics show the low effectiveness of measures to reduce environmental risks in the Russian Federation. Based on information provided by the OECD "Green Growth Indicators", from January to July 2018, it was revealed:

- environmental pollution

- pollution of water bodies

- soil pollution

Chita, Barnaul and Ulan-Ude were identified ae the riskiest regions [3]. In this regard, it should be said that any enterprise belonging to any industry can and does harm the environmental situation, but a number of industrial enterprises cause the greatest harm within their industry specificity, these include:

- extraction of minerals and oil;

- energy industry;

- metallurgy;

- electrical and electronic equipment;

- transport;

- pulp and paper production;

- non-production waste;

- chemical production;

- production of plastic and various building materials;

- enterprises of the military-industrial complex. 


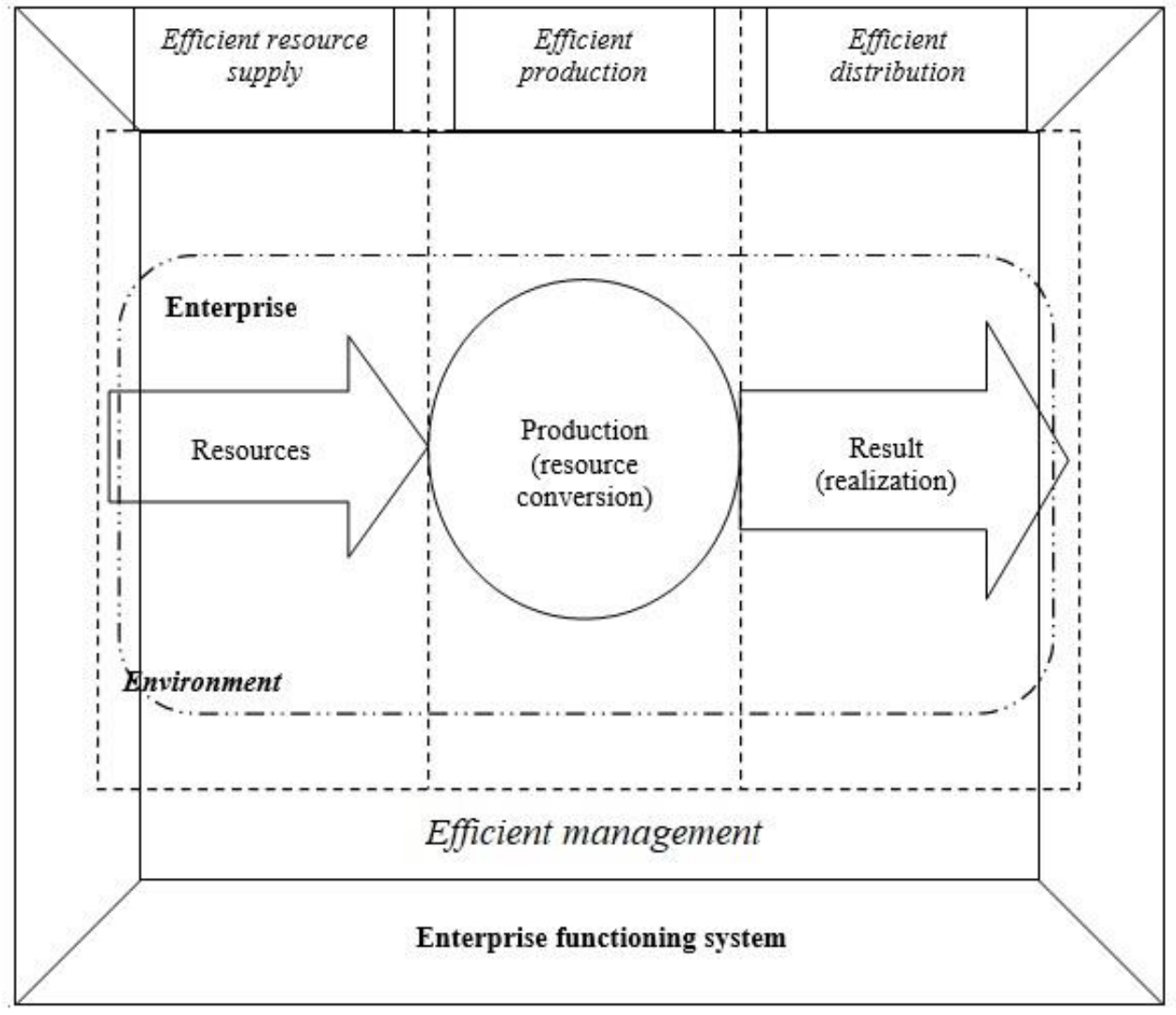

Fig. 2. System of effective functioning of an industrial enterprise

Negative consequences of the functioning of these industrial enterprises cause such environmental problems as pollution of the soil, water bodies, atmosphere, which affects agricultural production, since products made from contaminated agricultural raw materials adversely affect the health of the country's population. In megapolises, this situation is particularly critical, which is associated with exhaust emissions and high electricity costs. And this problem is already becoming global, for example, an excess of the exhaust gases in the air is observed in 40 cities of the Russian Federation. Below is the rating of regions of the Russian Federation The rating was conducted by the Russian public organization "Green Patrol" at the end of 2018. 
Table 1. Ecological rating of subjects of the Russian Federation [4]

\begin{tabular}{|l|l|l|}
\hline \multicolumn{1}{|c|}{$\begin{array}{c}\text { Regions with positive } \\
\text { dynamics }\end{array}$} & $\begin{array}{c}\text { Regions with average values } \\
\text { of indicators }\end{array}$ & \multicolumn{1}{|c|}{$\begin{array}{c}\text { Regions with negative } \\
\text { dynamics }\end{array}$} \\
\hline Tambov Region & Chuvash Republic & Orenburg Region \\
Altai Republic & Moscow & Krasnoyarsk Region \\
Altai Krai & Chukotka & Jewish Autonomous Oblast \\
Kursk Region & Perm Krai & Nizhny Novgorod Region \\
Komi Republic & Vologda Region & Bryansk Region \\
Murmansk Region & Tomsk Region & Moscow Region \\
St. Petersburg & Tyumen Region & Irkutsk Region \\
Magadan Region & Rostov Region & Chelyabinsk Region \\
Ulyanovsk Region & Yaroslavl Region & Sverdlovsk Region \\
& Smolensk Region & \\
& Transbaikal Krai & \\
& Republic of Kalmykia & \\
& Republic of Sakha (Yakutia) & \\
& Tula Region and others. & \\
\hline
\end{tabular}

When fulfilling its obligations to reduce environmental risks, an industrial enterprise must choose an optimal trajectory with certain parameters: quality, cost, and time [5]. It involves the effective functioning and development of the organization [6]:

- by providing the necessary quantity and quality of resources;

- highly qualified personnel;

- complete, open and accessible information;

Effective distribution and sales activities directly associated with the marketing system of the enterprise, which is fully responsible for the quality management of sales of finished products to the final consumer [7]. From the point of view of marketing and logistics, such a conjugated approach leads to an increase in sales volumes and customer satisfaction. Thus, an integrated approach to the logistics and marketing activities of an industrial enterprise greatly increases its effective functioning [8].

The problem of environmental risks is directly related to the inefficient allocation of resources, which leads to disequilibrium and the generation of imbalances in the socioeconomic system. The transition to efficient distribution increases the viability of some participants in the distribution process without compromising the security of other participants. On the basis of the principle of Pareto efficiency, it should be noted that the best option, in which there is no alternative that is more preferable for at least one of the participants in the distribution, is an efficient allocation of limited resources.

Nevertheless, we note the difficulties in the formation of the effective functioning of an industrial enterprise. These difficulties include the fact that the final result, which determines the effective work, is formed by the transformation of particular indicators into a generalized system of indicators on the basis of synthesis. As a result of this process, factors influencing the effective functioning of an industrial enterprise and its impact on the environmental situation in the region are determined. As a rule, factors are multidirectional and unpredictable in relation to the activities of an enterprise and the environment, which increases not only the level of uncertainty, but also the risk associated with the production and sale of poor-quality final product. Factors can be both external and internal. They can be controlled by an enterprise or not controlled. This classification allows providing a detailed picture of the system of functioning of an enterprise in terms of interaction with the external environment, assessing the results of the enterprise's activities, and determining which influence groups can be managed and regulated, and which ones are not.

External and internal factors of effective functioning form a single system within which they interact. External relations can strengthen or neutralize the effect of internal factors. 
Internal factors determine the strength or weakness of the influence of external factors (Figure 3) [9].

\begin{tabular}{|c|c|}
\hline External factors: & $\begin{array}{c}\text { Internal factors: } \\
\text { political situation, } \\
\text { economic situation, } \\
\text { environmental situation, } \\
\text { scientific and technical progress, } \\
\text { information support }\end{array}$ \\
technics and technology, \\
R\&D, \\
production, \\
finance, \\
organizational structure, \\
personnel, \\
strategy
\end{tabular}

Fig. 3. Classification of external and internal factors

Internal factors are key for enterprises, since the main barriers that impede the enterprise to function effectively are determined in a stable economy. They are in the sphere of its own activity and contain internal contradictions about the goals of the enterprise, the means of their achievement, resources, methods of organizing activities and management to achieve the goals [10].

External factors do not depend on the activities of the enterprise; therefore, they are difficult to control and practically uncontrollable. But their impact on the effective functioning of the enterprise is quite high. The long-term development of the enterprise, the duration of its life cycle depends on the socio-economic, environmental, political and other.

External factors do not depend on the activities of the enterprise. Therefore, they are difficult to control and almost uncontrollable. But their influence on the effective functioning of the enterprise is quite high. The long-term development of the enterprise, the duration of its life cycle, depends on the socio-economic, environmental, political and other factors.

There are external factors of direct and indirect influence. The combination of factors of direct influence of the external environment on the functioning and development of an enterprise is called objective external factors. This group of factors includes suppliers of material, financial, labor, information and other resources, as well as consumers, partners and competitors. Also, this group includes certain laws and regulations that also have a significant impact on the effective functioning of an enterprise.

Another group of external factors is subjective external factors, which are a set of environmental factors that indirectly affect the operation of an enterprise [11]. The state of the economy, natural, socio-political factors, etc. play the role of background factors that promote or hinder the effective functioning and sustainable development of an enterprise.

The above mentioned classification of factors for the effective functioning of an industrial enterprise is not comprehensive, because the uniqueness of each enterprise cannot be neglected. Any business entity has his own internal and external factors that have a certain impact on its activities. However, these factors can be defined as universal, because they influence the development of enterprises of various business branches in one way or another.

Possible directions for the implementation of internal and external factors for the effective functioning of an enterprise differ in the power of influence, degree of utilization, and level of control. For making management decisions, it is important to know exactly the scale of action, forms of control, etc. Each of the factors affecting the effective functioning of an enterprise has the ability to manifest itself at various levels and acts with certain time delays, during which the current activity of the business entity adapts to the environmental influences and to the intrastructural reorganization, changing the functioning strategy. 
After analyzing the most significant factors affecting the functioning of an enterprise, we can conclude that each element of the economic system affects the activity of an enterprise in one way or another. Thus, it must be taken into account when setting goals, objectives and strategies for the development of an enterprise. However, for the implementation of a comprehensive assessment of the enterprise activities, it is necessary to apply a unified approach and form an integrated system of factors of effective functioning [12].

Unfortunately, the conditions in which a modern enterprise has to function cannot be described as favorable. Studies show that today growth rates in the main industries are not high, and some continue to fall down, which leads to increased competition and poses a number of serious problems for Russian industrial enterprises [13]. For example, according to the Federal State Statistics Service, the production index of enterprises in the manufacturing industry showed an ambiguous dynamics over the past decade, and even negative over the past five years (Figure 4).

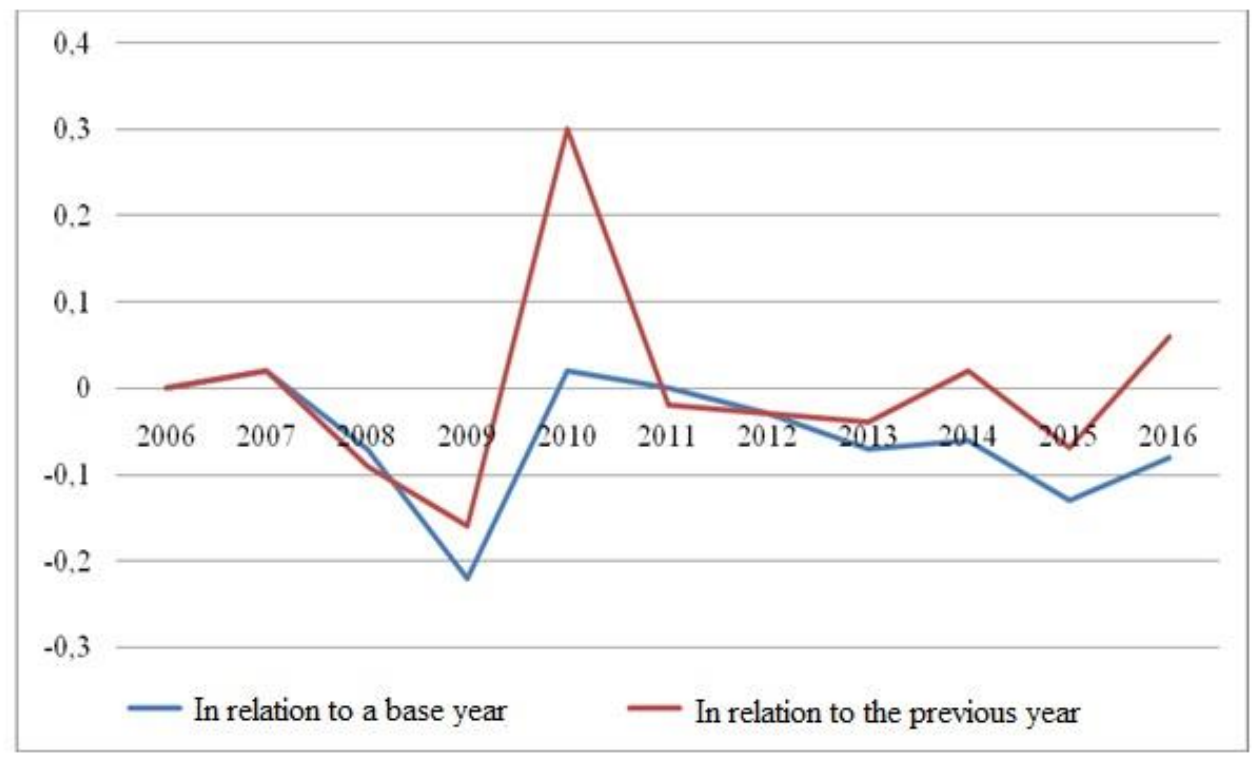

Fig. 4. Chart of the production index for the manufacturing industry, 2006 - 2016

The accumulated foreign and domestic practical experience suggests that the reasons for the formation of an inefficient functioning of an enterprise can be very diverse. Each industrial enterprise is unique and has its own strengths and weaknesses. However, there are some common problems that most domestic enterprises face. The analysis of the most significant factors constraining the growth of domestic manufacturing enterprises can be carried out on the basis of the results of a survey of managers of industrial enterprises, which is conducted monthly by the Federal State Statistics Service (Figure 5). 


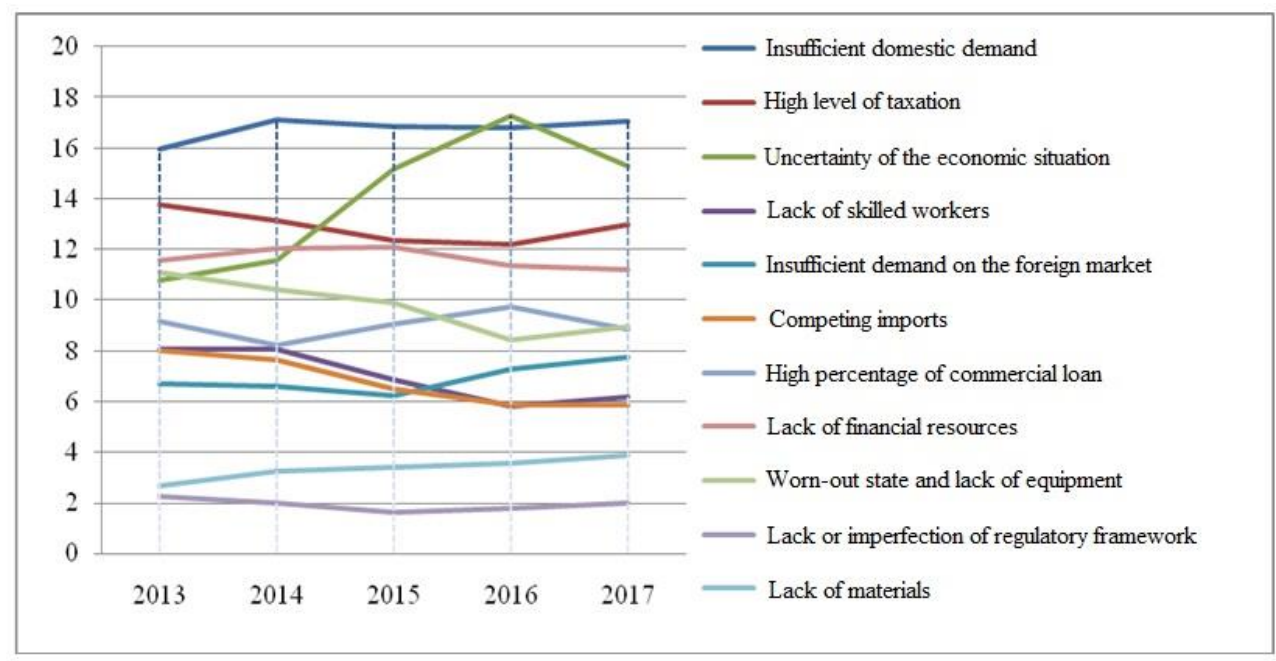

Fig. 5. Dynamics of factors constraining the production growth of manufacturing enterprises, $\%$ of the number of respondents, 2013-2017

The study of the concept of effective functioning determined the need to form a system of effective functioning of an industrial enterprise as the only possible option for the development of domestic enterprises in the context of improving the quality system of enterprises and reducing environmental risks [14]. It is necessary to ensure the maximum realization of the potential at all stages of the life cycle, from effective resource saving to efficient distribution of products, taking into account the principles of effective management of all processes interrelated with the environment.

\section{Conclusion}

Thus, the considered issues of the effective functioning of an industrial enterprise, regions with negative and positive dynamics of the development from the environmental point of view revealed that it is necessary to develop risk management methods, and this is the most priority direction in solving problematic aspects in socio-economic systems. Recently, development trends and environmental risk management issues have increasingly been given attention by domestic and foreign researchers, politicians and entrepreneurs.

\section{References}

1. http://berichnow.ru/stati/kontseptsiya-deyatelnosti-predpriyatiya-napravleniedeystviy\#ixzz4bmVbyUD6 (Last accessed: 02.02.2019)

2. M. A. Shishelov, Otsenka klyuchevykh faktorov rosta effektivnosti derevoobrabatyvayushchey promyshlennosti (na primere Respubliki Komi), (in Russian) dissertation of PhD in Economics, 162 (Moscow, 2015)

3. https://vawilon.ru/jekologicheskaja-statistika/\#zagryaznenie-okruzhayushhej-sredy-v-rf (Last accessed: 01.02.2019)

4. URL: http://ecopress.center/page3586539.html (Last accessed: 01.02.2019)

5. M. E. Orlova, Razvitiye mekhanizmov effektivnogo funktsionirovaniya promyshlennogo predpriyatiya: dissertation of PhD in Economics (Moscow, 2007) 
6. http://cyberleninka.ru/article/n/resursoobespechennost-osnova-ekonomicheskoybezopasnosti-organizatsiy-agrarnoy-sfery (Last accessed: 29.01.2019).

7. V. N. Naumov, Razvitiye printsipov marketinga vzaimodeystviya dlya upravleniya kanalami sbyta, Problemy sovremennoy ekonomiki, 2, 222-226 (2008)

8. http://e-koncept.ru/2016/86702.htm (Last accessed: 01.02.2019)

9. V. Yu. Glebov, Upravleniye effektivnostyu promyshlennykh predpriyatiy na osnove kooperatsii ikh deyatelnosti: abstract of thesis, dissertation of $\mathrm{PhD}$ in Economics, 23 (Moscow, 2012)

10. URL: http://www.science-education.ru/ru/article/view?id=18044 (Last accessed: 01.02.2019).

11. http://www.fundamental-research.ru/ru/article/view?id=33759 (Last accessed: 01.02.2019)

12. T. S. Kochegarova, A. A. Kopyltsov, The efficiency of functioning of enterprises in various sectors of the economy, Strategies and tools for managing the economy: sectoral and regional aspect: Proceedings of the VI International Scientific and Practical Conference, 2, 343- 348 (St. Petersburg, April 14-16, 2016)

13. O. P. Bodyakov, Sovershenstvovaniye institutsionalnoy sredy kak faktor povysheniya effektivnosti funktsionirovaniya promyshlennykh predpriyatiy (na primere myasnoy promyshlennosti Krasnodarskogo kraya): abstract of thesis, dissertation of $\mathrm{PhD}$ in Economics, 24 (Krasnodar, 2012)

14. A. R. Bril, O. V. Kalinina, I. V. Ilin, A. S. Dubgorn, O. Y. Iliashenko, Forecasting the turnover growth in the risk management system as management decisions support. Proceedings of 2017 20th IEEE International Conference on Soft Computing and Measurements, SCM 2017. 6 July 692-693, (2017) 